\title{
IgG Index
}

National Cancer Institute

\section{Source}

National Cancer Institute. Ig G Index. NCI Thesaurus. Code C154735.

A relative measurement (ratio) of the Ig $\mathrm{G}$ in cerebrospinal fluid to IgG in serum in a sample. 